\title{
Tell me Still, Angola \\ the False Thing that is Dystopia
}

Solange Evangelista Luis ${ }^{a}$ (1)

\begin{abstract}
José Luis Mendonça's book Angola, me diz ainda (2017) brings together poems from the 1980s to 2016, unveiling a constellation of images that express the unfulfilled utopian Angolan dream. Although his poems gravitate around his personal experiences, they reflect a collective past. They can be understood as what Walter Benjamin called monads: historical objects (BENJAMIN, 2006, p. 262) based on the poet's own experiences, full of meaning, emotions, feelings, and dreams. Through these monadic poems, his poetry establishes a dialogue with the past. The poet's dystopic present is that of an Angola distanced from the dream manifested in the insubmissive poetry of Agostinho Neto and of the Message Generation, which incited decolonization through a liberation struggle and projected a utopian new nation. Mendonça revisits Neto's Message Generation and its appeal to discover Angola: unveiling a nation with a broken dream and a dystopic present, denouncing a future that is still to come. The poet's monads do not dwell on dystopia but wrestle conformism, fanning the spark of hope (BENJAMIN, 2006, p. 391). They expose what Adorno named the false thing (BLOCH, 1996, p. 12), sparking the longing for something true: reminding the reader that transformation is inevitable.
\end{abstract}

Keywords: Angolan Literature. José Luís Mendonça. Lusophone African Literature. Dystopia. Walter Benjamin.

\footnotetext{
a Universidade do Porto, Centro de Estudos Africanos, Porto, Portugal

E-mail: luissolange@hotmail.com
} 
A map of the world that does not include Utopia is not even worth glancing at.

Oscar Wilde apud BLOCH, 1996, p. 16
1 Except for Agostinho Neto's poetry, all translations presented in this article were done by its author, given that José Luis Mendonça's poetry has not yet been translated into English.
José Luís Mendonça is a prolific award-winning Angolan author, born in 1955, in Golungo Alto. He made his debut in 1981 with a collection of poems entitled Chuva Novembrina [November's Rain ${ }^{1}$, that won him the Sacred Hope Literary Award - the highest of its kind in Angola. From then on, Mendonça's literary path has been replete with awards, not only for poetry but also for novels, short stories and children's books. His works have been published in Angola, Portugal, Brazil, and Germany. His poetic production is representative of the hermetic poetry of post-independence Angola, but his book Angola, me diz ainda [Tell me still, Angola] deviates from this tendency.

Through a collection of autobiographical poems that expand from the 1980s to 2016, Tell me still, Angola (2017) offers the readers a constellation of images that express the unfulfilled utopian Angolan dream, as the poet observes his chaotic and unnerving present of fear, silence, violence and corruption. Although these poems reveal his personal experiences, they also reflect a collective ordeal. They can be understood as what Walter Benjamin referred to as monads, where "thinking suddenly comes to a stop" (BENJAMIN, 2006, xvii, p. 396).

While entrenched in the dystopic Angolan present, the poet establishes a dialogue with the poetry of Agostinho Neto and of his generation, which permeated Mendonça's youth and inspired his literary epoch. The pre-independence revolutionary poetry that disseminated the dream of a utopia-like new nation inspired the struggle for freedom whilst providing the tropes, the values and the ideology that would also guide Angola through the complex context of postindependence civil war.

By sharing his monadic poems, the poet blasts the homogeneity of the narrative continuum of Angolan history, written from the perspective of the ruling class (BENJAMIN, 2006, p. 391). The past, charged with what Walter Benjamin called Jetztzeit (BENJAMIN, 2006, p. 395), the time ripe with 
2 According to Jacoby (2005, p. 7), “J. Max Patrick, a co-editor of an anthology of utopian writings, coined the term" but Jacoby credits John Stuart Mill for using the term for the first time in a parliament debate about Ireland (around 1867-8). revolutionary possibility, is brought to a standstill (c.f. Benjamin) in Mendonça's poems. By blasting his unique experiences out of the ruling class' instrumental historicism, he crystallizes them (BENJAMIN, 2006, p. 396), allowing them to escape a silenced and sterile past. Benjamin perceives this blasting intervention as "the dialectical leap Marx understood as revolution" (BENJAMIN, 2006, p. 395). The monadic poem is here observed as the "historical object" (BENJAMIN, 2006, p. 396) where the "revolutionary chance" lies (BENJAMIN, 2006, p. 396).

As David S. Ferris observes, the blasting proposed by Benjamin is not a "destructive undertaking but rather a restructuring of history that seeks to preserve the objects it attends to while allowing the emergence of what has been oppressed in the past" (FERRIS, 2008, p. 131). For Benjamin, "[h]istoricism presents the eternal image of the past, whereas historical materialism presents a given experience with the past" (BENJAMIN, 2006, p. 262). Thus, the poet blasts his "historical objects" into the present, disrupting the continuum of history, adding to the understanding of history "whose pulse can be felt in the present" (BENJAMIN, 2006, p. 262), "leading to a consciousness of the present" (BENJAMIN, 2006, p. 262), the "now of recognizability" (BENJAMIN, 1999, p. 464) - the "dialectical point of rupture: awakening" (BENJAMIN, 1999, p. 464).

As Jacoby points out, the "failure of Soviet communism entailed the end of utopia" (JACOBY, 2005, p. 5-6), but it did not negate hope. According to Jacoby, the word utopia "coined by Thomas More, breathed of possibility" (JACOBY, 2005, p. 6), whereas the term dystopia ${ }^{2}$ came to be understood "as the contrary of utopia" (JACOBY, 2005, p. 7). Mendonça's poems do not intend to dwell on dystopia, but to offer redemption from a void historicism that proposes no hope. In a present burdened with the aftermath of colonialism, civil war, corruption, oppression and poverty, Mendonça's monadic poems are the "true image[s] of the past [that] flits by" (BENJAMIN, 2006, p. 390), flashing up "in a moment of danger" (BENJAMIN, 2006, p. 391) to wrestle conformism, thus "fanning the spark of hope" (BENJAMIN, 2006, p. 391).

Although Mendonça's dystopic monads speak about the loss of a utopian-like nation as they unveil a desolated present, they do not intend to sketch a future or provide blueprints (c.f. 
${ }^{3}$ See "Something's Missing: A discussion between Ernst Bloch and Theodor $W$. Adorno on the contradictions of utopian longing" (BLOCH, 1996, p. 1-17).
4 PIDE (Polícia

Internacional e de

Defesa do Estado)

was a state security agency of Estado Novo.

It became infamous for its torture mechanisms, and pernicious covert cells' organization, capable of infiltrating grassroots political movements in its territory and beyond - giving PIDE indisputable control of many aspects of Portuguese daily life, being absolutely daunting.
Jacoby) for a new utopia. His poetry may be understood within the framework of what Russell Jacoby referred to as iconoclastic utopianism, "that listens for, but does not look into the future [] [...] that pines for the future, but does not map it out", that does not offer a "blueprint" for it (JACOBY, 2005, p. 119). For iconoclastic utopians, there is a longing for something that cannot be described, only felt and only hoped for. According to Theodor Adorno, himself an iconoclast, "insofar as we do not know what the correct thing would be, we know exactly... what the false thing is", and thus, "the true thing determines itself via the false thing" ${ }^{\prime \prime}$ (BLOCH, 1996, p. 11-12 apud JACOBY, 2005, p. 147). Mendonça denounces the Angolan dystopia as he presents his objects of history. Although his poems offer no blueprint for the future, they unveil the false thing ( $c f$. Adorno) of the present - which is not utopia. The poet's monads, teeming with the possibility of change, shine their light, exposing the false thing, bringing about the longing for something true.

\section{Angolan poetry as the disruptor of history's narrative continuum: the imagining of the utopic nation}

From the early action of the Nativist Free Press (which between 1850 and 1885 overtly questioned colonialism), until the independence in 1975, literature has always played a major role in promoting political awareness in Angola. It was within literature, especially within poetry, that Angola as a nation was first imagined, conceived, and its idea disseminated.

After the 1926 coup d'état, the Estado Novo [New State] ruled Portugal from 1933 to 1974. António de Oliveira Salazar was the Prime Minister of this Dictatorial Regime from 1932 to 1968. It was during his period of extreme censorship and oppression that poetry intensely defended the humanitarian values that influenced what later came to be known as Angola's 50s Generation or Message Generation. Given PIDE's ${ }^{4}$ notoriously rigid censorship, young Angolan intellectuals adopted poetry as a venue to denounce colonial atrocities. As poets try to emulate and represent those who have been silenced by fear, the Angolan pre-independence poetry carries, woven in its body through coded language, undeniable traces of the historical context which dictated its aesthetics, ethics, and themes. Each poem, representing the poet's experience and longing, encapsulates the totality of an era. 
5 The association's

name means

"those born in

Angola" (Naturais)

Differentiating

themselves (as those

"born in Angola") from

a supposedly cultural

homogeneous and

seamless Portuguese

identity was, notably,

a bold cultural and

political stand.

${ }^{6}$ This means, in

Kimbundo

(an Angolan

Bantu language),

"children of Angola"

$(\mathrm{ANA}=$ children +

NGOLA=Angola)

(LARANJEIRA, 1995,

p. 71).
In 1948, the Novos Intelectuais de Angola (MNIA) [the New Intellectuals' Movement of Angola] emerged from the Associação dos Naturais de Angola 5 [The Association of Angolan Natives], the ANANGOLA ${ }^{6}$, in Luanda. This movement had the maxim Let's discover Angola! [Vamos descobrir Angola!], which launched a cultural and nationalist project calling for the "discovery" of an Angolan identity. These young intellectuals rejected and denounced the assimilationist agenda of the colonial regime, which imposed an educational curriculum that promoted not only Portuguese cultural, geographic and historical aspects, but also Salazarian values and dogmas. The MNIA undermined the Portuguese Age of Discovery's claim to have "discovered" Angola, by insisting that the nation's reality and essence were still unknown. Whereas their maxim proposed the discovery, its exclamation point called for its celebration. Their aim was to create an Angolan literature that would encompass cultural, geographical and social aspects ignored not only by Portuguese institutions (like the educational system) but also by colonial literature - highly charged with Estado Novo's ideology. Colonial literature flourished during Estado Novo and offered an imperialist, patronizing and racist view of its colonies. It had the colonizer at its center - portrayed as a hero in the hostile African landscape. The colonized were tertiary characters, devoid of depth and diminished in their statures as human beings (LARANJEIRA, 1998, p. 73). They were depicted as uncivilized, uncultured, indolent primitive savages or as docile and obedient, submissive to European culture and Christian values, and respectful of the colonial order (LARANJEIRA, 1998, p. 73). According to Laranjeira, this narrative tradition had its origins in travel literature (LARANJEIRA, 1998, p. 74). The themes of the first colonial texts revolved around Europeans' exotic adventures in Africa, written by travellers to amuse Metropolitan readers (LARANJEIRA, 1995, p. 37). Later, as the Estado Novo's imperialist objectives crystallized, they were written mainly by government officials and settlers. The Angolan poet and scholar Mário António Fernandes de Oliveira evidenced that this literature promoted colonial ideological propaganda and order, having at its core the Estado Novo imperialist ideal of Portuguese nationalism. Oliveira discusses how colonial literature was purposely promoted by government contests, becoming institutionalized, 
7 See also Alberto Oliveira Pinto, Angola e as retóricas coloniais. Luanda:

Caxinde, 2012; and Russell G.

Hamilton, Voices from an Empire. Minneapolis: University of Minnesota Press, 1975, a precursor in discussing this subject.

${ }^{8}$ For bibliography in English see Phyllis Peres, Transculturation and resistance in Lusophone African narrative. Gainesville: University Press of Florida, 1997; and also Barbara Harlow, Resistance Literature. New York: Metheun 1987.

${ }^{9}$ See Inocência Mata, A Casa dos Estudantes do Império e o lugar da literatura na consciencialização política. Lisbon: UCCLA, 2015.

${ }^{10}$ See

MANGORRINHA, et al., 2016.

11 Oliveira perceived them as creole (OLIVEIRA, 1997, p. 145), whereas Laranjeira speaks of "regionalism" (LARANJEIRA, 1995, p. 49). Voz de Angola was a response to a racist article published in a Luanda's newspaper. These responses were compiled in a book, which was financed, published and sold, in 1901, by its own writers (OLIVEIRA, 1997, p. 139). permeating the literary landscape to disseminate colonialist ideology (OLIVEIRA, 1997, p. 189-248). As a reaction to this standardization of colonial contemn and silencing, the New Intellectuals' Movement of Angola placed the colonized, and the perniciousness of colonialism, at the center of their artistic production ${ }^{7}$.

It is widely recognized that Portuguese Neo-Realism and Brazilian Modernism, amongst others, influenced this movement (LARANJEIRA, 1995) ${ }^{8}$. Both movements, with their own aesthetics and philosophies, advocated for the insertion of life's reality into the text. By bringing the experience of the colonized into literature, the text becomes not only a space for cultural identity construction but also a place for anticolonialism. Simultaneously, in Portugal, young people from the Portuguese colonies, studying in Lisbon, fraternized at the Casa dos Estudantes do Império - CEI [The Empire Students' House]'. This house, created by the Estado Novo as a means of propagating the Empire's ideal of a cohesive Portuguese Colonial unity, soon became a fertile ground to covertly discuss, during seemingly innocuous cultural soirées, the downfall of imperialism. Future liberation movement leaders, such as Agostinho Neto and Amílcar Cabral, as well as some of the most prominent upcoming Lusophone African writers, gathered at CEI. In 1948, CEI published a bulletin called Mensagem ${ }^{10}[$ Message]. This publication was followed by a homologous publication in Luanda in 1951, evidencing the ideological synchronicity between Luanda and Lisbon's youth. The ANANGOLA's cultural department published the magazine Mensagem, with a revealing subtitle: $a$ Voz dos Naturais de Angola [the Voice of Those born in Angola]. The organizers of Message may have had in mind the first collective protest publication in Angola, organized by the native journalist elite: Voz de Angola Clamando no Deserto - Oferecida aos Amigos da Verdade pelos Naturais [Voice of Angola Clamouring in the Desert Offered to Friends of the Truth by those born in Angola]. The word Naturais, which implies those "born in" Angola, resonates the "nativist spirit" (LARANJEIRA, 1995, p. 50) attributed to most of the African writers at the turn of the century, who understood themselves as "filhos da terra" [children of the land] (OLIVEIRA, 1997, p. 138) ${ }^{11}$. This publication emerged in a context dominated 
12 The Message generation produced writers who became freedom-fighters, and freedom-fighters who wrote poetry, and poets who only fought with words. Agostinho Neto, Mário António, Alda Lara, Viriato da Cruz, António Jacinto, Uanhenga Xitu, and Alexandre Dáskalos are only a few

representatives of this remarkable generation who envisioned a utopian world free of colonialism.

\footnotetext{
13 "MENSAGEM será - nós o queremos! - o marco iniciador de uma Cultura Nova, de Angola e por Angola, [...] a Cultura de Angola, somatório dos nossos esforços; a Cultura de Angola, [...] verdadeira como a verdade do nosso Querer; pujante, como a pujança da nossa Mocidade; humana como a humanidade que lhe imprimirá a auscultação dos nossos problemas, a compreensão do nosso Povo e a vontade que a todos nos irmanará, de nos compreendermos e sermos compreendidos [...]" (ANANGOLA, 1951 apud FERREIRA, 1997, p. 91-92).

14 The Angolan author Pepetela, in his novel Geração da Utopia [Utopia Generation], depicts this generation and their historical context.

15 "In our land/ the bullets begin to flower" are the last two verses of Jorge Rebelo's poem "Vem contar-me o teu destino, irmão" (In ANDRADE, 1980, p. 78). The last verse is also the title of Margaret Dickinson's combat poetry anthology When Bullets Begin to Flower, published by East African Publishing House in 1972.
}

by colonial ideology, and was heavily monitored by PIDE who eventually censored and banned it. This generation's poems, "constantly call[ed] into question every victory, past and present, of the rulers" (BENJAMIN, 2006, p. 390). They contained the "spiritual things" (BENJAMIN, 2006, p. 390), that is, the aspirations, feelings and the ideology of an entire generation $^{12}$. In the inaugural issue of Mensagem, the young organizers made their intentions known:

\begin{abstract}
MESSAGE will be - we want it! - the initiator of a New Culture, from Angola and for Angola, fundamentally Angolan, [...] the Culture of Angola, the sum of our efforts; the Culture of Angola, [...] true as the truth of our Want; vigorous as the strength of our Youth; human as the humanity that will inscribe in it the auscultation of our problems, the understanding of our People, and the will to understand and to be understood that unites us all [...] $]^{13}$ (ANANGOLA, 1951 apud FERREIRA, 1997, p. 91-92)
\end{abstract}

By bringing the "Culture of Angola", "our problems" and "our People" into the literary text, that generation of Angolans not only defined the guidelines for their identity search but also announced their nationalist political stand. These publications became landmarks and beacons for future cultural and literary productions. That generation is often referred to as Geração da Mensagem [Message Generation], Geração de 50 [1950s Generation], and Geração da Utopia ${ }^{14}$ [Utopia Generation] - to cite a few denominations.

Angolan nationalist poetry was a space not only for anticolonial struggle but also for imagining the longed-for nation. As the dream for freedom took on increasingly political contours, the poetry became more politicized, relying less on coded language, becoming freer as it became more clandestine - functioning as a vehicle for political awareness. As it followed political action, poetry became a libertarian call for armed struggle, prevalent in what the Angolan anthologist Mário de Andrade called O Canto Armado [The Armed Chant] (ANDRADE, 1980) of the liberated areas. This poetry imagined a utopian nation that, given the violence of colonialism, was also created through violence, death and sacrifice. In combat poetry as in the hinterland, bullets began to flower ${ }^{15}$, signifying the relentlessness of spring's renewal. 
16 União Nacional para a Independência Total de Angola [National Union for the Total Independence of Angola].

${ }^{17}$ Movimento Popular de Libertação de Angola [Popular Movement for the Liberation of Angola].

${ }^{18}$ Frente Nacional de Libertação de Angola [National Front for the Liberation of Angola].

19 According to Oliveira Pinto (2017, p. 737), the Portuguese Government met with the three Liberation Movements on January 15 of 1975 at Alvor,

Portugal. This treaty defined a transitional government, where MPLA, FNLA and UNITA were all represented.

\footnotetext{
${ }^{20}$ Amnesty

International speaks of 30.000 to 90.000 dead.

See "The orphans of Angola's secret massacre seek the truth", September 5, 2020, BBC NEWS, online November 13 , 2020, at https://www. bbc.com/news/worldafrica-54025264; See also Lara Pawson, In the Name of the People. London: Bloomsbury, 2014.
}

\section{Angolan literature and the collapse of the utopian dream: the dystopic "now of recognizability"}

Contrary to what Angolans dreamed, the end of colonialism did not bring peace. Confrontations for the control of the capital city of Luanda began shortly after the three liberation movements (UNITA ${ }^{16}$, MPLA ${ }^{17}$, and FNLA ${ }^{18}$ ) signed the Alvor Treaty ${ }^{19}$, meant to establish a transitional government in 1975. After FNLA and UNITA retreated from Luanda, MPLA proclaimed the independence of Angola. Violent confrontations between MPLA and UNITA continued thereafter. The fulfillment of the utopian dream was put on hold while Angola's fratricidal war ran from 1975 to 2002, with brief interludes, amidst a series of exceedingly violent events.

One of these events, memorialized by its date, 27 May 1977, is possibly the most atrocious and barbaric episode in Angola's history. The actions of 27 May came to be understood as a response to an attempted coup d'état by a dissenting wing of the MPLA. This intent was brutally and violently suppressed, leading to arbitrary arrests, torture and murder across the country throughout 1977 and later. There is much disagreement about the events that led to this terrible occurrence, which is still shrouded in silence. Thousands of people vanished; their bodies are yet to be found ${ }^{20}$.

Fear and silence were the legacies left by colonialism given its oppression, punishments and PIDE's torturous tactics. The horrific events of 27 May took deep roots in the Angolan collective memory, further silencing already traumatized Angolans. Fear was intensified by the horrors of the civil war and the suspicion it bred. The barbaric acts of violence perpetrated by both militarized parties to halt internal dissidences created a perpetual climate of fear: ready to be instrumentalized.

The trajectory of the Angolan dream was thus hopelessly "obliterated" (MAIMONA, 1984), giving way to a dystopic existence where silence became self-imposed by absolute and paralyzing fear. Fear and silence became as if culturally entrenched, permeating generations to come - which did not experience colonialism, wars, or 27 May, but have them indelibly, almost as if genetically, imprinted. Faced with the impossibility of expressing the unspeakable of war and 
death, the poet camouflages their truth in the text. Aesthetics and language allow them to weave a web of silences about unfulfilled wartime love, uncertainty, terror, pain, but also delights (DÁSKALOS, 2003), eroticism and sensuality.

These poets turned to their inner world to survive the disenchantment and the turmoil around them. Laranjeira called it inner-exile (LARANJEIRA, 2013). They concerned themselves with metapoetry - toiling in search of an individual poetic voice. They cloistered their poetry in obscure language, becoming hermetic, not as a way to evade the war and its consequences, but as a mechanism of coping and resistance: exalting love to defeat hate, worshiping beauty to overcome horror, praising rhythm and melody to muffle dissonance, and celebrating symmetry to conquer disarray. The barbarity of war is implicit in the silence of what is left unsaid.

In 2002, Jonas Savimbi, the leader of UNITA was killed, bringing the civil war to a long-awaited end. The country began a process of peace building, national reconciliation and reconstruction: families, bridges, loves, roads, dreams, and trajectories, derailed by the civil war, are now resumed, mended or rebuilt. The MPLA continued to rule Angola through this new era without strong political opposition. As the rising price of oil greatly increased Angola's wealth, the moment presented itself fecund with possibilities, despite its challenges and complexities. With peace came the revival of hope. The marred nation attempted to recoup its dream's obliterated trajectory in a dystopic postwar context of trauma, extreme partisanship, illiteracy, poverty, and near total destruction of the social and economic fabric.

\section{Tell me still, Angola - waiting for the flowers: the cycle continues}

By the time Mendonça published his book, Angola, me diz ainda [Tell me still, Angola], fifteen years had passed since the armistice, but the Angolan dream was still far from being a reality. Misery continues to plague Angolans struggling daily for survival against extreme poverty, hunger, power shortages, lack of running water, homelessness, disease, and obscurantism. 
${ }^{21}$ In 2017, the year the book was published, Angola had just elected João Lourenço as its new president, which secured the MPLA's uninterrupted rule since independence. During his campaign, Lourenço promised to eradicate corruption and to improve freedom of expression of the press.

22 See Mendonça's interview (TRINDADE, 2019).

${ }^{23}$ Kimbundo word meaning rumour.

\footnotetext{
${ }^{24}$ Also spelled Uanhenga Xitu, the pseudonym for Agostinho André Mendes de Carvalho. He was a nurse and an Angolan nationalist, who was imprisoned by PIDE from 1959 to 1970 - where he began to write. After independence, he became Health Minister, having also held other governmental positions. His novel, O Ministro [The Minister] unveils, through his fictionalization of history (from the 1970s until the 1990s), the corruption that was taking root and further deviating Angola from its utopian project.

${ }^{25}$ See LUIS, 2015 and TOPA, 2018.
}

José Luís Mendonça lived through colonialism, decolonization, the euphoria of independence, the eruption of the civil war and the downfall of the utopian dream, only to have the dream rekindled by the peace process and again damaged by ruinous corruption. His book brings together poems from the 1980s to $2016^{21}$, based on the poet's own experiences ${ }^{22}$, full of meaning, emotions, feelings, and expectations, through the entire process. From the "now-time" and through these experiences, his poetry establishes a dialogue with the past: "[h] grasps the constellation into which his own era has entered, along with a very specific earlier one. Thus[,] he establishes a conception of the present as a now-time shot through with splinters of messianic time" (BENJAMIN, 2006, p. 397). The poet's dystopic "now-time" is that of an Angola distanced from the dream manifested in the insubmissive poetry of Agostinho Neto and the Message Generation - poetry that incited decolonization through a liberation struggle and projected in and through it a utopian new nation.

Tell me still, Angola is composed of three parts: the first, also titled "Tell me still, Angola" focuses on the poet's relationship with Angola's dystopic present as the central theme. The second part, "Munjimbo ${ }^{23}$ of cicadas" presents the Angolan poet's views and experiences with Africa and the World. In the third and last part, "Poetics for a wax museum", the poet presents a tribute to the heroes of the past who fought for Angolan utopia. This tribute contemplates five poems for five people. The first is "Hoji Ya Henda", a poem for a young MPLA freedom-fighter who was killed in combat and became a national hero. The second poem, "To the Comrade Killed in 1975", is a eulogy to the unknown Angolan soldier.

In the third poem, Mendonça revisits the postindependence era to expose the fate of "Ricardo de Mello", a journalist assassinated by a bullet to the head in 1992 for denouncing high-level corruption in the government's war effort. The fourth poem honours "Maria do Carmo Medina", a Portuguese lawyer who fought for human rights and liberties during colonialism. Medina remained in Angola after independence, where, as an Angolan citizen, she helped to design the new country's legal system. "Wanhenga Xitu"24, was a freedom-fighter arrested by PIDE who became a writer 
in prison. He is the fifth person of this wax museum to be celebrated. This is also the book's last poem. Here Xitu, the storyteller, is beseeched to return from the dead. All these heroes epitomize important roles for the independence of Angola: the combatants, the journalist, the lawyer and the storyteller. All of them are capable of becoming disruptive forces of change. Much like the poet, the journalist and the storyteller present us with narratives that can diverge from official historicism, becoming dissonant splinters of messianic time in the historical narrative.

While Mendonça closes the book with a poem advocating for the return of the storyteller who exposed colonialism and post-independence corruption, he opens it with a poem of another freedom-fighter: Agostinho Neto. Both authors were references of resistance for Mendonça's generation. The poem "Farewell at the hour of parting" is a poem that condemns the colonial regime. Mendonça chose the following excerpts of Neto's poem to open his book:

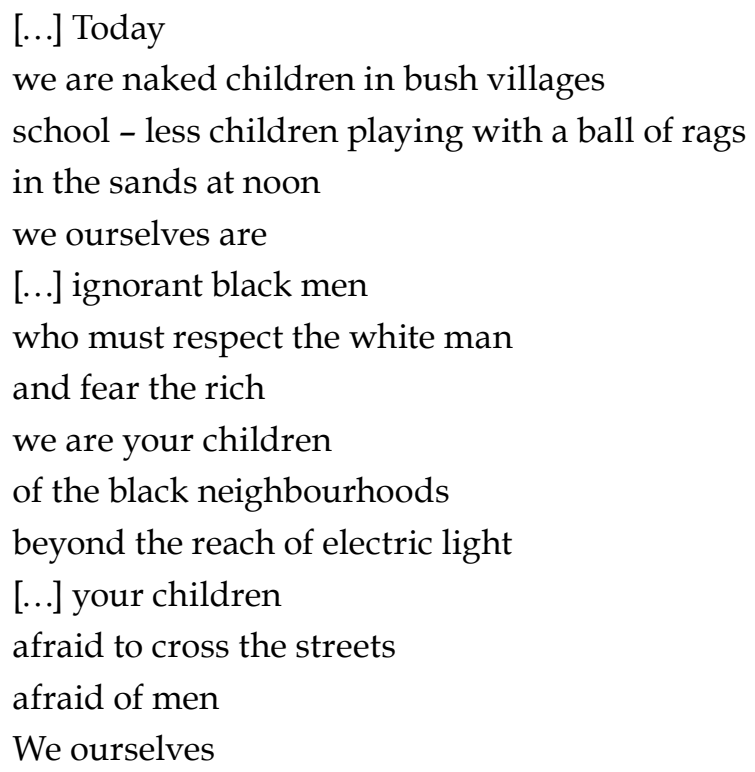

These excerpts expose and emphasize two aspects of colonial life: poverty and fear. Poverty is flagrant in the children's nakedness and illiteracy, in the absence of asphalt, and the lack of electricity - revealing obscurantism and 
${ }^{26}$ Benjamin

understood catastrophe as a basic historical underdevelopment. For Neto, fear is a constant presence during the colonial era, revealed in the most mundane actions. As Mendonça's poems disclose, these issues are still present in Angola. Mendonça revisits Neto's Message Generation's appeal to discover Angola: unveiling a nation with a broken dream and a dystopic present, denouncing a future that is still to come.

In the majority of poems from this collection, Mendonça relinquishes the hermetic language characteristic of postindependence poetry. Without disregarding aesthetic qualities, he opts for a more functional language ${ }^{25}$, characteristic of the Message Generation poetry, which intended to lead the reader through a process of political awakening - seeking their alignment against colonial occupation. This option marks Mendonça's aesthetic choice, substantiated by the emblematic images of the present day and by the dialogue it establishes with a past of resistance poetry against colonialism.

Walter Benjamin's approach to history presents itself as a valuable contribution to better understand Mendonça's dialogue with the past. In "On the Concept of History", a part of Theses XVI and XVII, Benjamin offers a distinction between "historicism" and "Materialist historiography". For him, "[h]istoricism offers the 'eternal' image of the past, [while] historical materialism supplies a unique experience with the past" (BENJAMIN, 2006, p. 396), where possibility lies. Benjamin understands Historicism as accumulative and sterile as "it musters a mass of data to fill the homogeneous, empty time" (BENJAMIN, 2006, p. 396) that "rightly culminates in universal history" (BENJAMIN, 2006, p. 396). "Materialist historiography, on the other hand, is based on a constructive principle" (BENJAMIN, 2006, p. 396). He adds:

Thinking involves not only the movement of thoughts, but their arrest as well. Where thinking suddenly comes to a stop in a constellation saturated with tensions, it gives that constellation a shock, by which thinking is crystallized as a monad. The historical materialist approaches a historical object only where it confronts him as a monad. (BENJAMIN, 2006, p. 396)

A monad is both a "crystallized thought" and a "historical object". In The Origin of German Tragic Drama, Benjamin explains the concept of the monad, which he borrows from Leibniz's 
Discourse on Metaphysics, in that "every single monad contains, in an indistinct way, all the others" (BENJAMIN, 2003, p. 47), making the monad all-encompassing. "The idea is a monad that means briefly: every idea contains the image of the world" (BENJAMIN, 2003, p. 48). The monad is thus panoptic, for it conceals in itself the totality of all the constellation's tensions. For Benjamin, these are moments of shock, of "arrested thought" when "time [...] come[s] to a standstill" (BENJAMIN, 2006, p. 396) and is crystallized in a monad (BENJAMIN, 2006, p. 396). The monad has the power to disrupt the continuity of history, allowing for a "revolutionary chance" (BENJAMIN, 2006, p. 396):

The historical materialist approaches a historical object only where it confronts him as a monad. In this structure he recognizes the sign of a messianic arrest of happening, or (to put it differently) a revolutionary chance in the fight for the oppressed past. (BENJAMIN, 2006, p. 396)

For Benjamin, the customary "conception of history" (BENJAMIN, 2006, p. 393) is a trap since it doesn't allow for "recognizability" (BENJAMIN, 2006, p. 390). For Walter Benjamin, recognizability happens in a fleeting moment, as the "true image of the past flits by" (BENJAMIN, 2006, p. 390), as it "flashes" (BENJAMIN, 2006, p. 390) "and is never seen again" (BENJAMIN, 2006, p. 390). This a moment imbued with possibilities. In the Arcades Project, "On the Theory of Knowledge, Theory of Progress", Benjamin explains that

It is not that what is past casts its light on what is present, or what is present its light on what is past; rather, image is that wherein what has been comes together in a flash with the now to form a constellation. In other words, image is dialectics at a standstill. (BENJAMIN, 1999, p. 462)

Benjamin adds that "[e]very present day is determined by the images that are synchronic with it: each 'now' is the now of a particular recognizability" (BENJAMIN, 1999, p. 462-463). Thus, "recognizability" happens in a particular time - the "now" - which he understands as "life's supremely dialectical point of rupture: awakening" (BENJAMIN, 1999, p. 464). The "now" of awakening, which is the moment of recognizability and rupture, is contained in a monad, a crystallized thought, 
concept, meaning "to have missed the opportunity" (BENJAMIN, 1999, p.
27 "Praça da nãoindependência/Não temos casa nem pão/ os combatentes da revolução/ tirou-nos tudo a burguesia/ colonial e pós colonial, olhai/ como ficaram magros os ventos/ dos punhos cerrados do povo. // Ontem fomos kalashnikoves/ hoje somos o poema mutilado/ na praça da não-independência/ o colono rouba a cor da floresta/ e tem a mesma língua húmida/ comprida e veloz do camaleão.

${ }^{28}$ Praça da independência/ Já temos casa já temos a "dialectical image" - expelled from the continuum of a historical process - that encapsulates both past and present (BENJAMIN, 1999, p. 475).

Situated in a dystopian present, Mendonça selects fragments of his personal experience, loaded with feelings and ideas which are reflexive of a collective history. His book is an assemblage of monads that spark political awakening and, with it, the possibility of change. Mendonça presents them as a "constellation of dangers" (BENJAMIN, 1999, p. 475) and "tensions" (BENJAMIN, 1999, p. 475), where the past is still present in the "now" as the title of his book suggests. These monads, his historical objects, are "blasted out of the continuum of historical succession" (BENJAMIN, 1999, p. 475), disrupting it by flashing a "now" of "recognizability". Within these monads lie both: the recognition of the catastrophe ${ }^{26}$ regarding the missed utopian dream, and its consequence, the dystopian present:

This structure first comes to light in the extracted object itself. And it does so in the form of the historical confrontation that makes up the interior (and, as it were, the bowels) of the historical object, and into which all the forces and interests of history enter on a reduced scale. (BENJAMIN, 1999, p. 475)

In Mendonça's poems, "Non-independence square" and "Independence square", "historical confrontation" materializes when past and present interpenetrate. This interpenetration renders the differences between them nearly imperceptible:

Non-independence square ${ }^{27}$

We have no home we have no bread the fighters for the revolution all have been taken by the bourgeoisie colonial and post-colonial, look how meager became the winds of people's clenched fists.

Yesterday we were Kalashnikovs today we are the mutilated poem in the non-independence square the colonizer steals the forest's colour and has the same moist tongue long and fast as a chameleon's

(MENDONÇA, 2017, p. 15) 
pão/ os combatentes

da revolução./

Devolveu-nos tudo

a burguesia/da

bandeira-monumento,

olhai/como o sol filtra

a luz do amanhã/

nos andaimes de um

povo a construir-

se.//Ontem fomos

gritos mastigados/

em gargantas secas de

exílio/hoje somos o

poema que enfim/se

tornou matéria-prima

de cantar/um canto

de batuque a semear/

flores na praça da

independência.

${ }^{29}$ Drumming.

30 The poem "Night" is most emblematic in its use of night to
The "Non-independence square" is the fifth poem of the first part of the book, whereas "Independence square" is the last:

Independence square ${ }^{28}$

We now have house we now have bread

the fighters for the revolution.

It gave us all back the bourgeoisie

of the flag-monument, look

how the sun filters tomorrow's light

on the scaffolds where a people build themselves.

Yesterday we were masticated screams

in dry throats of exile

today we are the poem that finally

became raw material for singing

a batuque ${ }^{29}$ chant sows

flowers in the independence square.

(MENDONÇA, 2017, p. 57)

Independence Square is situated in Luanda. It was from there that Agostinho Neto announced the independence of Angola. Since then, the square has been through many changes. Today, a statue of Neto stands in its center holding its right fist in the air, clenched as if in eternal defiance, solidarity, resistance and protest: attitudes that marked Neto's generation's writing and political actions. In recent years, the Independence square has been used by youth protestors, given its symbolism, as a place to demonstrate their indignation against oppression and corruption. Since then, Neto's statue has witnessed the brutal suppression of Angola's youth by police wielding batons, as the new generations increasingly discard their inherited fear and demand their dreams.

These poems are similar in their structure, both having 12 lines and very similar verses, with subtle but significant differences. There is a fluidic interpenetration of past and present imagery, which makes it difficult for the reader to determine, immediately, the exact historical moment where the actions in the poem take place and, thus, determine if the poet refers to the pre or post-independence era.

The theme of the poem "Non-independence square" is the failure to reach the utopian dream, despite the "revolution" that did not bring the freedom-fighters either home or bread. The 
poet calls this a "non-independence" place, where the looting of the land and the exploitation of the poor by a "bourgeoisie/ colonial and post-colonial" continues. He laments the enfeeblement of people's power, represented by the weakening of the "clenched fists [']" wind of change, while he remembers that, in the past, they fought colonialism with Kalashnikovs. Now they are the "mutilated poem" of the Message Generation - the mutilated dream. The colonizer of today "steals the forest's colour" and with it the hope of renewal, regeneration and growth. He is chameleon-like, changing his appearance to adapt to the new environment without changing his essence. His tongue is still "long and fast" and moist with lies to better catch his prey, the people.

"Independence square" maintains the same structure as the "Non-independence square" and, in some ways, is like a mirror image of the first poem - almost its negation. Here the combatants have gotten back all that has been taken away from them by the bourgeoisie: they now have house and bread. Whereas yesterday they were silenced, they were "the mutilated poem", today they are "the poem that finally became [the] raw material for singing". This is no longer a people whose fists' wind is feeble. Yesterday's suffocated "screams" and "dry throats" now give way to new singing and drumming at the Independence Square.

Within the time encompassed by this book, Angola went through a series of protests taken to this square by a younger generation who refused inner-exile (LARANJEIRA, 2013), but drummed and sowed "flowers in the independence square". Their drumming breaks the long silence maintained by violence and fear. The flowers bring to mind Neto's poem "A bouquet of roses for you" (NETO, 1974, p. 59), where the flowers announce the undefeatable and "imminent spring" (NETO, 1974, p. 60-61), "pregnant with force" (NETO, 1974, p. 60). Thus, "Independence square" projects the outcome of a natural cycle: independence, like spring, is predestined and unstoppable. Whereas "Non-independence square" speaks of the dystopic post-independence context, "Independence square" presents itself as its antithesis, as the projection of a possibility.

The first part of Angola, me diz ainda [Tell me still, Angola] (that shares the same title with the book) opens with a poem by Agostinho Neto, which represents his generation's nationalist 
condemnation of colonialism and call for revolution. "Nonindependence square" follows it by giving continuity to the Message Generation's aesthetics and intention of denouncing the colonizers. Only this time, the colonizers are themselves Angolans who steal the "forest's colour", the green (associated with spring) representing the possibility of renewal. The poet is part of the Angolan collective experience: "we [...] the fighters for the revolution", homeless and hungry, robbed of the utopian dream and hope, weakened and mutilated by war and fear, caught in the chameleon's viscous tongue. The poet's individual experience is also the nation's experience, which he recreates in a poem - a monad that contains in itself the poet's arrested thought, his moment of recognizability, crystallized and shared with the readers, who in turn may be able to undergo their own moment of recognizability. Here lies the revolutionary chance Benjamin advocates. When read together, and as a part of a constellation charged with tensions, these dystopic poems spark hope.

"Independence square" celebrates the sowing of flowers, presenting the inevitability of renewal, and with it, the hope of new possibilities. Benjamin's Historical Materialism points to a constructive history, where the recognizability, inherent in the individual experience expressed in the monad, allows for the possibility of change, sparking hope. The constructive possibility relies on the poet's ability to construct a monad in which what is relevant in the past can be recognized in the present. Like the materialist historian, the poet has "to erect a slender but sturdy scaffolding - a philosophic structure - in order to draw the most vital aspects of the past into his net" (BENJAMIN, 1999, p. 459). The poet's book is his "philosophic structure" - "the scaffolds where a people build themselves" and where "tomorrow's light" is filtered by the natural and powerful light of the "the sun". This is the "sun which is rising in the sky of history" (BENJAMIN, 2006, p. 390), announcing the "most inconspicuous of all transformations" (BENJAMIN, 2006, p. 390). The possibilities of tomorrow are brought by the

represent colonialism and all its ailments (NETO, 1974, p. 17).

31 "Privatizaram os monumentos"/ Privatizaram os awakening of the people who build themselves, against and despite night's obscurantism (which is an image much used in Neto's poetry ${ }^{30}$ ). Daylight, like spring, is naturally cyclical, and therefore relentless. "The flowers", Benjamin reveals, 
monumentos./

Privatizaram as fábricas./Um dia privatizaram o lixo.//Privatizaram o inevitável deus do silêncio.//Privatizaram o sonho./Privatizaram a própria morte/nos jazigos do Alto das Cruzes.//Privatizaram o pão/privatizaram as libelinhas/que bailavam na borda branca do Kwanza.// Privatizaram a passada do semba/tomaram conta de tudo/e o povo só dança o Entrudo.//

Privatizaram

as catanas do 4

de Fevereiro./

Privatizaram a mão invisível do Estado/e

o Estado ficou sozinho com/a mentira bruta/e a esquizofrénica e desmedida/medula da prepotência.// Privatizaram o erário e os canários/que cantavam nas janelas da alma/e agora só sabemos que o amor/ anda fugido no exílio.//Privatizaram as estantes do sol na Cidade Alta/ privatizaram o mar, o céu e as estrelas//e o povo angolano entrou /na escuridão mercadológica/a morder os frutos da zunga/e a fugir porrada da polícia / com uma mão na frente e outra/ atrás do sonho que privatizaram.

${ }^{32}$ It is a distinguished cemetery in the neighbourhood of Miramar, in the capital city of Luanda. It has been, throughout history, the burial ground for most of Luanda's distinguished personalities.

${ }^{33}$ It is one of Angola's longest rivers. It empties into the Atlantic Ocean just south of Luanda.

Kwanza is also the name of Angola's currency.

${ }^{34}$ Semba is an Angolan traditional type of music and dance. "turn toward the sun [...] by dint of a secret heliotropism" (BENJAMIN, 2006, p. 390): transformation is inevitable.

A people who build themselves need to know their history, need to "constantly call into question every victory, past and present, of the rulers" (BENJAMIN, 2006, p. 390). Benjamin understands that historicism has "sympathize[d]" with the "victor" (BENJAMIN, 2006, p. 391), which "invariably benefits the current rulers" (BENJAMIN, 2006, p. 391):

Whoever has emerged victorious participates to this day in the triumphal procession in which current rulers step over those who are lying prostate. According to traditional practice, the spoils are carried in the procession. They are called "cultural treasures," and a historical materialist views them with cautious detachment. For in every case these treasures have a lineage which he cannot contemplate without horror. (BENJAMIN, 2006, p. 391)

Mendonça's generation watched as culture was instrumentalized to disseminate ideological values. Immediately after independence, poetry became instrumentalized by the ruling party. It was given a purpose: to extol the new country. It was summoned to participate in the "procession" of the victors. Tell me still, Angola refuses to be a "cultural treasure" in this sense. Much like the historical materialist, Mendonça acknowledges that these "treasures" are "never free of barbarism" (BENJAMIN, 2006, p. 392). To question the victor also implicates dissociation "from this process of transmission as far as possible. [The poet] regards it as his task to brush history against the grain" (BENJAMIN, 2006, p. 392).

In the poem "They privatized the monuments", Mendonça exposes the progressing appropriation of Angolan assets, culture and history:

They privatized the monuments. ${ }^{31}$

They privatized the factories.

One day they privatized the trash.

They privatized the inevitable god of silence.

They privatized the dream.

They privatized death

in the crypts of Alto das Cruzes ${ }^{32}$.

They privatized bread

privatized the dragonflies

that danced on the Kwanza's ${ }^{33}$ white edge. 


\footnotetext{
${ }^{35}$ It is a traditional

Portuguese celebration

that served as the basis

for carnival. In this

revelry, people play

pranks on each other. It

has been, traditionally,

a festivity for the poor.
${ }^{36}$ In February 1961, a
group of men armed
with machetes invaded
the São Paulo jailhouse
in Luanda. Their
attack was contained.
The date became
a national holiday,
meant to celebrate
the beginning of the
freedom-fighting
struggle by MPLA.
${ }^{37}$ It is the
Parliament House's
neighbourhood in
Luanda.
${ }^{38}$ Zungar means selling goods on the street.
39 "agora o nosso show (é já)/na avenida dos massacres/ às 15 horas

\author{
They privatized Semba's ${ }^{34}$ steps \\ they took over everything \\ and the people only dance the Entrudo ${ }^{35}$. \\ They privatized the machetes of February $4^{36}$. \\ Privatized the invisible hand of the State \\ and the State was left alone with \\ the gross lie \\ and the schizophrenic and immeasurable \\ marrow of tyranny.
}

They privatized public funds and the canaries

that sang in the windows of the soul

and now all we know is that love

is a fugitive in exile.

They privatized the sun's shelves of Cidade Alta ${ }^{37}$

privatized the sea, the sky and the stars

and the Angolan people entered

the obscure market logic

biting the fruits of the zunga ${ }^{38}$

and dodging police beatings

with one hand while the other

tries to catch the privatized dream.

(MENDONÇA, 2017, p. 13)

The privatization denounced by Mendonça goes beyond the appropriation of material and cultural assets and history: it envelopes the seizing of the Angolan dream. "They took over everything" even the "god of silence" - meaning that even the MPLA, with its muzzling authoritarianism, has been privatized. The dream envisioned by the writers of the Message Generation - most of them MPLA members - has been "privatized" and subverted. "They" have made the nation their private domain.

The privatization of monuments reveals an attempt to control historicity and collective memory through the control of its remembrance objects and "cultural treasures". Mendonça exposes the problem of "the disintegration of culture into goods which become objects of possession" (BENJAMIN, 2006, p. 267), leaving them vulnerable to instrumentalization.

As a symbolic gesture of reclaiming Angola from colonial occupation, changes were made to the new country's toponymy. Colonial statues were removed from public places, 
nos toponimizando".

"Toponomizando"

- a play on the

word "toponímia"/

toponymy.

40 "O poeta sobe

Mafumeiras",

Mafumeira is a tree. while public structures, edifices, places and streets were renamed. The names of colonial figures and events were now substituted by guerrilla-fighters' and commemorative dates from MPLA - history's victor. Thus, the violence that forged Angola was further woven and imprinted in its collective memory through the "privatization" of the country's historical events and toponymization of its spaces with memories and mementos of warfare. The poem "brazil avenue" unveils a glimpse of the violence that pervades Angola's toponymization:

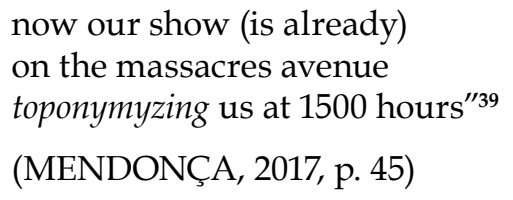

Not long after independence, Luanda's Brazil Avenue was renamed Hoji Ya Henda. Henda is venerated as a young and notable MPLA hero killed in combat against the colonial power. However, before the official renaming, locals referred to the street as Massacres Avenue [Avenida dos Massacres]. Months before the independence of Angola, during the transitional government, the three independence movements had armed confrontations in Luanda, leading to the failure of the Alvor Treaty. The struggle to control the capital city of Luanda became fiercer between MPLA and FNLA, which historian MabekoTali called Batalha de Luanda [Luanda's Battle] (MABEKO-TALI, 2018, p. 459). One of the most brutal of these confrontations took place at Brazil Avenue, near FNLA's headquarters. The bloody carnage of that day led the people of Luanda to rename the avenue.

The different struggles and battles during pre and postindependence eras left their indelible marks on the country. Angola's colonial toponymy, replaced by war remembrances, meant to exalt the sacrifices for the nation, further calcified the war in the collective memory. The continuing omnipresence of it is a constant reminder of the fragility of a "state of emergency" present (BENJAMIN, 2006, p. 392). The possibility of war looms over Angola, and fear of it is often instrumentalized.

For Benjamin, "[a]rticulating the past historically does not mean recognizing it the way it really was" (BENJAMIN, 2006, p. 391): 
Historical materialism wishes to hold fast that image of the past which unexpectedly appears to the historical subject in a moment of danger. The danger threatens both the content of the tradition and those who inherit it. For both, it is one and the same thing: the danger of becoming a tool of the ruling classes. (BENJAMIN, 2006, p. 391)

The "danger" Benjamin speaks of is implicit in the poem, for they "[p]rivatized death/in the crypts of Alto das Cruzes". The dead and their past, inscribed in "the content of tradition", had been seized and privatized. The poet "is firmly convinced that even the dead will not be safe from the enemy if he is victorious. And this enemy has never ceased to be victorious" (BENJAMIN, 2006, p. 391). Victory has permitted "them" to dictate the past and its essence, thus determining the present. The poet's monads are moments of recognizability that disrupt the continued "privatization" of Angola: the past has become a "tool of the ruling class". In his "now" of recognizability (BENJAMIN, 1999, p. 463) lies the possibility of the "nonindependence square" ultimately become the "independence square" - as his monads disrupt the continuum of history and crystallize the inevitability of a new cycle - where "flowers" will grow and poems will sing.

Mendonça's monadic poems are moments of recognizability: "critical momentum[s]" (BENJAMIN, 1999, p. 475) that disrupt ideological instrumentalization. For Benjamin,

the destructive momentum in materialist historiography is to be conceived as the reaction to a constellation of dangers [...] In this constellation is comprised its actuality; against its threat, it must prove its presence of mind. (BENJAMIN, 1999, p. 475)

Mendonça's book unveils a dystopic constellation of Angolan dangers. Against it, the poet brings forth his "presence of mind" crystallized in his monadic poems that, like "lightning flashes" (BENJAMIN, 1999, p. 475), disrupt, illuminate and expose the "gross lie" or - as Adorno would call it - the false thing (BLOCH, 1996, p. 12).

Mendonça, much like the historical materialist, understands that the past, or [the] "tradition of the oppressed [,] teaches us that the "state of emergency" in which we live 
is not the exception but the rule" (BENJAMIN, 2006, p. 392). Therefore:

We must attain to a conception of history that accords with this insight. Then we will clearly see that it is our task to bring about a real state of emergency, and this will improve our position in the struggle against fascism. (BENJAMIN, 2006, p. 392)

Upon illuminating the gross lie - the false thing - Mendonça unveils the "real state of emergency". For Benjamin, "[t]he current amazement that the things we are experiencing are "still" possible in the twentieth century is not philosophical" (BENJAMIN, 2006, p. 392), but the result of a false belief that the state of emergency is a norm. The title reflects an Angolan colloquialism where the adverb "still" replaces the adverb "no" in answers regarding achievements or accomplishments. It also denotes the stagnation of the Angolan dream. Furthermore, what Angola still has to tell is "its actuality": that "all have been taken by the bourgeoisie/colonial and post-colonial" and that despite a liberation movement, fear and violence still rein. The title suggests that it is in the telling of personal experiences (the objects of history) and in the consequent disruption of the victor's "state of emergency" narrative that "possibility" thrives. The title urges Angola to tell its own stories so that "the truth will not run away from us" (BENJAMIN, 2006, p. 390).

\section{The iconoclastic utopian poet}

In the poem "Independence square", the sun announces "transformations". However, the poet's constructed images do not reveal how the transformed world will look. The poem does not offer a blueprint of this new Independence square, apart from the celebratory flowers and singing. Mendonça's monadic poems shock and awake the reader, but they do not articulate what lies beyond the awakening. It offers a lightening moment, a flash of possibility where revolution and change lie, but not an image of it in itself.

His poetry may be understood within the framework of what Russell Jacoby referred to as iconoclastic utopianism. Jacoby distinguishes between what he considers to be two "currents of utopian thought: the blueprint tradition and the iconoclastic tradition" (JACOBY, 2005, p. xv): 
[i]n the utopian tradition, virtually all attention is focused on what may be called the 'blueprint' school of utopianism. [...] blueprint utopians have detailed what the future will look like; they have set it out; they have elaborated; they have demarcated it. (JACOBY, 2005, p. 31)

In opposition to the blueprint school, Jacoby writes about what he considers to be less-noticed and more complex utopians: the "anti-blueprint utopians [or] iconoclastic utopians":

Rather than elaborate the future in precise detail, they longed, waited, or worked for utopia but did not visualize it. The iconoclastic utopians tapped ideas traditionally associated with utopia - harmony, leisure, peace, and pleasure - but rather than spelling it out what could be, they kept, as it were, their ears open toward it. Ears and eyes are opposite, for insofar as they did not visualize the future, they listened for it. They did not privilege the eye, but the ear. (JACOBY, 2005, p. 32-33)

Mendonça, in his poem "The poet climbs Mafumeiras" 40 , "reminds the eyes [...] who has bronze in the ear" (MENDONÇA, 2017, p. 48). The poet's bronze in the ear is a reminder that utopia is to be listened to in the music sang at Independence Square. It is something that cannot be described, only felt and hoped for. Theodor W. Adorno, himself a utopian iconoclast (JACOBY, 2005, p. 147), in conversation with Ernst Bloch about utopian longing, discourses on how "utopia is essentially in the determined negation [...] of that which merely is, and by concretizing itself as something false, it always points at the same time to what should be" (BLOCH, 1996, p. 12). "Falsum - the false thing - index sui et veri" (BLOCH, 1996, p. 12): " $\mathrm{t}]$ he false is the sign of itself and the correct" (BLOCH, 1996, p. 12). "That means that the true thing determines itself via the false thing, or via that which makes itself falsely known" (BLOCH, 1996, p. 12). He further clarifies: "insofar as we do not know what the correct thing would be, we know exactly, to be sure, what the false thing is" (BLOCH, 1996, p. 12). It is in the denouncing and consequent negation of the dystopic present that Mendonça's utopianism becomes substantiated. Despite offering no image of it, the poet believes, much like Adorno

that all humans deep down, whether they admit this or not, know that it would be possible or it could be different. Not 
only could they live without hunger and probably without anxiety, but they could also live as free human beings. (BLOCH, 1996, p. 4)

As Jacoby explains, "the reluctance to depict utopia does not diminish but exalts it [, for it] refuses to reduce the unknown future to the well-known present, the hope to its cause" (JACOBY, 2005, p. 26). Despite not giving its precise measurements and blueprints, Mendonça's poems long for a society of which he can only offer its dystopian image: a false thing - that which is not utopia.

\section{The long roll of thunder and the spark of hope - longing for utopia}

Like "the herald who invites the dead to the table" (BENJAMIN, 1999, p. 481), Mendonça dialogues with the poetry of Agostinho Neto, whose generation imagined and fought for a utopian nation. In its poetry, the Message Generation projected the dreamt nation while denounced the lie of colonialism and its dehumanizing civilizational project - the false thing.

Mendonça, in his disruptive process of brushing history against the grain, blasts his monads from the victor's sterile continuum of history where otherwise they would be trapped, silenced and neutralized. They contain within themselves both the unfulfilled dream of the past and the dystopic present full of Jetztzeit, the "now-time" - ripe with possibility. In this possibility lies the hope for a revolutionary chance.

He invites the dead to the table, for they are not safe from the enemy if he is victorious. The dead are the keepers of the past that, together with the "no-time" of the present, can disrupt the gross lie the victors have told: that the state of emergency is the norm. Dystopia is not the norm - it is the false thing that propels the poet to continue longing for utopia.

Mendonça's monads shock with their dystopic imagery of hurtful experiences, misery, fear, violence, corruption and overall dehumanization. His poems remind the reader that hope is resilient, that "hope still nails a flag on the mast, even in decline, [...] even when this decline is still very strong" (BLOCH, 1996, p. 17). If dystopia is dehumanization, it is a false thing - its negation could only be what Bloch called "real 
humanism" which is the substance of hope (BLOCH, 1977, p. 389 apud ZIPES, 1996, p. xxv).

Mendonça offers his lighting flash experiences in a book that is a "long roll of thunder" (BENJAMIN, 1999, p. 475). It "explodes the homogeneity of the epoch, interspersing it with ruins - that is, with the present" (BENJAMIN, 1999, p. 474). Mendonça's monads are the ruins of the utopic dream, imprinted in the Angolan collective memory. They disrupt the continuity of historicism's gross lie. They do not intend to grieve the loss of the utopian nation, but to "wrestle conformism" (BENJAMIN, 2006, p. 391) and awaken the possibility of something other than the false thing that is the Angolan dystopia. Tell me still, Angola is thus a long roll of thunder "fanning the spark of hope" (BENJAMIN, 2006, p. 391).

\section{REFERENCES}

ANDRADE, Mário de. Antologia Temática de Poesia Africana II: o canto armado. 2nd ed. Praia (Cap-Vert): Instituto Caboverdeano do Livro, 1980.

BENJAMIN, Walter. Selected Writings (1938-1940). Vol. 4. Michael W. Jennings (ed.). Cambridge: Harvard University Press, 2006.

. The Origin of German Tragic Drama. Trans. John Osborne. London: Verso, 2003.

Selected Writings (1935-1938). Vol.3. Howard Eliand and Michael W. Jennings (ed.). Trans. Edmund Jephcott, Howard Eliand, et al. Cambridge: Harvard University Press, 2002.

The Arcades Project. Trans. Howard Eiland and Kevin McLaughlin. Cambridge: Harvard University Press, 1999.

BLOCH, Ernst. Something is Missing: A Discussion Between Ernst Bloch and Theodor W. Adorno on the Contradictions of Utopian Longing. In: BLOCH, Ernst. The Utopian Function of Art and Literature: Selected Essays. 4th ed. Cambridge: MIT Press, 1996. p. 1-16. 
DÁSKALOS, Maria Alexandre. Jardim das Delícias. Lisbon: Caminho, 2003.

FERREIRA, Manuel. No Reino de Caliban II. 3rd ed. Lisbon: Plátano Editora, 1997.

FERRIS, David S. The Cambridge Introduction to Walter Benjamin. Cambridge: Cambridge University Press, 2008.

JACOBY, Russell. Picture Imperfect: Utopian Thought for an Anti-Utopian Age. New York: Columbia University Press, 2005.

LARANJEIRA, Pires. Preface. In: FEIJÓO, Lopito K. Cartas de Amor. Cerveira: Nóssomos Lda., 2013.

. Literatura Colonial Portuguesa. África, Revista do Centro de Estudos Africanos, USP, São Paulo, (20/21), p. 71-77, 1998. Available: http://www.revistas.usp.br/africa/article/ view/75036/78594 Accessed: 20 Jan. 2021

Literaturas Africanas de Expressão Portuguesa. Lisboa: Universidade Aberta, 1995.

LUIS, Solange E. A poesia angolana de resistência: a palavra, a AK-47, o silêncio e o microfone. 2015. 551 p. Doctoral Thesis (Lusophone African Literature) - Faculty of Arts and Humanities, Coimbra University, Coimbra, Portugal, 2015.

MABEKO-TALI, Jean-Michel. Guerrilhas e Lutas Sociais: o MPLA perante si próprio (1960-1977). Lisboa: Mercado de Letras Editores, 2018.

MAIMONA, João. Trajectória Obliterada. Luanda: Instituto Nacional do Livro e do Disco, 1984.

MANGORRINHA, Jorge, MEDINA, Fernando, RAMALHO Vítor \& FREUDENTHAL, Aida (org.). 1st ed. Casa dos Estudantes do Império: 1944-1965. Lisbon: Câmara Municipal de Lisboa, UCCLP, 2016. Available: http://comum.rcaap.pt/ bitstream/10400.26/19860/1/Cat\% C3\%A1logo\%20CEI.pdf Accessed: 11 Nov. 2020 
MENDONÇA, José Luís. Angola, me diz ainda. Luanda: Acácias Editora, 2017.

NETO, Agostinho. Sacred Hope. Trans. Marga Holness. Dar Es Salaam: Tanzania Publishing House, 1974.

OLIVEIRA, Mário António Fernandes de. A Formação da Literatura Angolana (1851-1950). Lisbon: Imprensa Nacional Casa da Moeda, 1997.

PINTO, Alberto Oliveira. História de Angola: Da Pré-História ao Início do Século XXI. 2nd ed. Lisbon: Mercado de Letras, 2017.

SECCO, Carmen Lúcia Tindó. Postcolonial Poetry in Cape Verde, Angola, and Mozambique: Some Contemporary Considerations. Research in African Literatures: Lusophone African and Afro-Brazilian Literatures, v.38, n. 1, p. 119-133, 2007.

TOPA, Francisco. Resenha a Angola, me diz ainda, de José Luís Mendonça. Interfacis, Belo Horizonte, v.4, n.1, p. 85-89, 2018. Available: http://facisaead.com.br/ojs/index.php/interfacis/ article/view/120 Accessed: 20 Sept. 2020

TRINDADE, João N'gola. Café da manhã com José Luís Mendonça. Cultura: Jornal Angolano de Artes e Letras. Luanda, 19 Dec. 2019. Available: http://jornalcultura.sapo.ao/grafitosna-alma/cafe-da-manha-com-jose-luis-mendonca Accessed: 10 Nov. 2020

ZIPES, Jack. Introduction: Towards a Realization of Anticipatory Illumination. In: Ernst Bloch, The Utopian Function of Art and Literature: Selected Essays. 4th ed. Cambridge: MIT Press, 1996. p. xi-xliii. 


\section{RESUMO}

\section{Angola, me diz ainda a coisa falsa que é Distopia}

O livro de José Luis Mendonça Angola, me diz ainda (2017) reúne poemas de 1980 a 2016 reveladores de uma constelação de imagens que expõem o sonho utópico angolano não realizado. Estes poemas podem ser entendidos como mônadas, termo utilizado por Walter Benjamin para designar objetos históricos (BENJAMIN, 2006, p. 262) que, embora se baseiem nas experiências do poeta, cheios de significado, emoções, sentimentos e sonhos, acabam por reflectir um passado colectivo. Por meio desses poemas mônadas, sua poesia estabelece um diálogo com o passado. O presente distópico do poeta é o de uma Angola distante do sonho manifestado na poesia insubmissa de Agostinho Neto e da Geração da Mensagem, que incitava à descolonização por intermédio da luta de libertação, enquanto projetava uma nação utópica. Mendonça revisita a Geração da Mensagem de Neto e seu apelo para descobrir Angola e assim desvenda uma nação com um sonho quebrado e um presente distópico, denunciando um futuro que ainda está por vir. As mônadas do poeta não são um sinal de prostração diante da distopia, mas de resistência ao conformismo - elas pretendem ser centelha da esperança (BENJAMIN, 2006, p. 391). Elas expõem a coisa falsa de que nos fala Adorno (BLOCH, 1996, p. 12), provocando o anseio por algo verdadeiro, lembrando ao leitor que a transformação é inevitável.

Palavras-Chave: Literatura Angolana. José Luís Mendonça. Literatura Lusófona. Distopia. Walter Benjamin. 
Solange Evagelista Luis é Professora Auxiliar no Instituto Superior de Ciências da Educação (ISCED) da Huíla, Lubango, Angola, nos Programas de Graduação e Pós-Graduação em Ensino da Língua Portuguesa. Doutora pela Universidade de Coimbra, Portugal, em Literaturas dos Países Africanos de Língua Oficial Portuguesa. Mestre pela Universidade de York, Toronto, Canadá, em Literatura Inglesa, com enfoque em Teoria PósColonial. Formação de base em Literatura Inglesa na Universidade Concordia, no Quebéc, Canadá. Professora convidada do Programa de Pós-Graduação em Ensino da História de África, pelo Departamento de Ciências Sociais do ISCED-Huíla. Participou em projectos de investigação em Angola, Portugal e Brasil. Desenvolve investigações sobre memória, identidade, resistência, violência e sexualidade no âmbito dos estudos pós-coloniais, africanos, subalternos, de gênero, culturais, modernos e pós-modernos. 